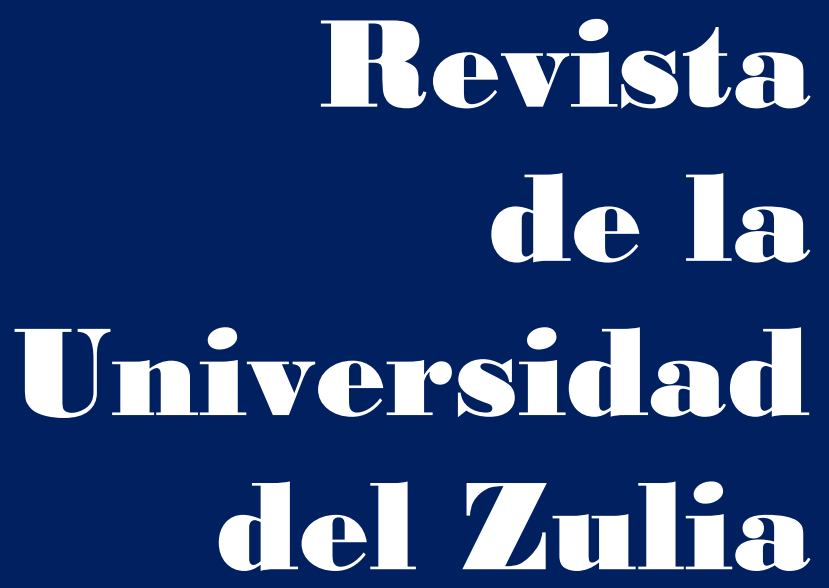

Fundada en 1947

por el Dr. Jesús Enrique Lossada

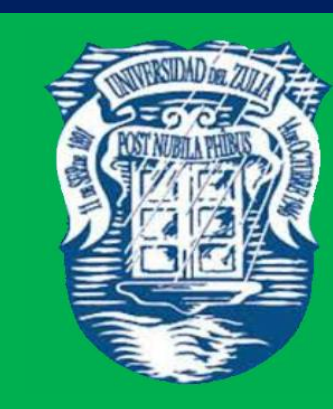

Ciencias del

Agrad,

Ingemiería

y Tecinología

\section{Aกัต 13 No $\mathbf{3 6}$} Enero - Abril 2022

Tercera Épaca

Maracailbo-Venezuela 
REVISTA DE LA UNIVERSIDAD DEL ZULIA. 3a época. Año 13 N 36, 2022

Yevhen Leheza et al. /// Foreign experience and international legal standards for the application ... 276-287 DOI: http://dx.doi.org/10.46925//rdluz.36.18

\title{
Foreign experience and international legal standards for the application of artificial intelligence in criminal proceedings
}

\author{
Yevhen Leheza * \\ Valentyn Len ** \\ Oleh Shkuta*** \\ Oleksiy Titarenko**** \\ Nataliia Cherniak*****
}

\begin{abstract}
The purpose of the research is to analyze the use of artificial intelligence in the justice systems of developed countries and the prospects for its use in criminal proceedings in Ukraine. Methodology: Research from the analysis of documentary sources; the basis is the dialectical method of knowledge of the facts of social reality, on which the formal legal and comparative legal approaches are largely based. Conclusions. In the near future, the accompanying organizational measures for the introduction of artificial intelligence and its regulatory support in public administrations (which are associated with the storage of big data, information processing based on mathematical algorithms and decision-making based on artificial intelligence) will be an integral component of life in our society. In fact, the use of artificial intelligence creates a model of digital decision automation. Such automation simplifies the decision-making procedure in similar procedures, which, of course, improves efficiency and simplifies the procedural decision-making procedure in terms of economy.

KEY WORDS: artificial intelligence; automation; computers; cybernetics; Legislation.
\end{abstract}

*Professor, Doctor of Science in law, Professor at the Department of Administrative and Customs Law, University of Customs and Finance, Ukraine. ORCID: https://orcid.org/0000-0001-9134-8499. E-mail: yevhenleheza@gmail.com

**Professor of Department of Public Law, Dnipro University of Technology. ORCID: https://orcid.org/00000002-1382-3335. E-mail: len.v.v.kpk@gmail.com

***Professor, Doctor of Science in law, Professor at the Department of Professional and Special Disciplines of Kherson Faculty, Odesa State University of Internal Affairs, Kherson, Ukraine. ORCID: https://orcid.org/0000-0003-0395-5710. E-mail: oleh_shkuts@ukr.net

****Associate professor, Doctor of Science in Law, Professor at the Department of Law enforcement activity and Criminal Law Disciplines, University of Customs and Finance, Ukraine. ORCID: https://orcid.org/00000002-3271-9402. E-mail: titarenkoaleksey1978@gmail.com

***** Associate Professor, Department of Criminal Procedure, Dnipropetrovsk State University of Internal Affairs 26 Gagarin Ave., Dnipro, 49005, Ukraine. ORCID: https://orcid.org/0000-0001-9494-7016. Email:Cherniak_nat@i.ua

Recibido: 01/10/2021

Aceptado: 29/11/2021 
REVISTA DE LA UNIVERSIDAD DEL ZULIA. 3a época. Año $13 \mathrm{~N}^{\circ}$ 36, 2022

Yevhen Leheza et al. /// Foreign experience and international legal standards for the application ... 276-287 DOI: http://dx.doi.org/10.46925//rdluz.36.18

\section{Experiencia extranjera y normas jurídicas internacionales para la aplicación de inteligencia artificial en procedimientos penales}

RESUMEN

El objetivo de la investigación es analizar el uso de la inteligencia artificial en los sistemas judiciales de los países desarrollados y las perspectivas de su uso en procesos penales en Ucrania. Metodología: Investigación a partir del análisis de fuentes documentales; la base es el método dialéctico de conocimiento de los hechos de la realidad social, en el que se basan en gran medida los enfoques jurídicos formales y jurídicos comparados. Conclusiones. En un futuro próximo, las medidas organizativas de acompañamiento para la implantación de la inteligencia artificial y su apoyo regulatorio en las administraciones públicas (que están asociadas al almacenamiento de big data, procesamiento de información basado en algoritmos matemáticos y toma de decisiones basada en inteligencia artificial) serán un componente integral de la vida en nuestra sociedad. De hecho, el uso de inteligencia artificial crea un modelo de automatización de decisiones digitales. Dicha automatización simplifica el procedimiento de toma de decisiones en procedimientos similares, lo que, por supuesto, mejora la eficiencia y simplifica el procedimiento de toma de decisiones en términos de economía.

PALABRAS CLAVE: inteligencia artificial; automatización; informática; cibernética; legislación.

\section{Introduction}

When analyzing the latest achievements in the sphere of Artificial Intelligence it must be recognized in the nearest future, accompanying organizational measures for introduction of artificial intelligence and its regulatory support in public authorities, which are associated with the storage of big data, information processing based on mathematical algorithms and decision-making based on artificial intelligence will be an integral component of life of our society.

Up to date artificial intelligence technologies are already being introduced in the judicial systems of China, the United States, Great Britain, France, and Argentina, they can with mathematical precision predict percentage of a court decision probability based on the respective algorithm and so they help to make court decisions in the respective proceedings. The mentioned artificial intelligence technologies use software and "machine learning" mathematical apparatus. 
REVISTA DE LA UNIVERSIDAD DEL ZULIA. 3a época. Año $13 \mathrm{~N}^{\circ}$ 36, 2022

Yevhen Leheza et al. /// Foreign experience and international legal standards for the application ... 276-287 DOI: http://dx.doi.org/10.46925//rdluz.36.18

Machine learning gives an opportunity to build a mathematical model of data, which includes a large number of variables unknown in advance. Parameters are configured gradually, during the learning phase, which uses learning data sets for search and classification. Various methods of machine learning are chosen by developers choose depending on the nature of tasks to be performed (grouped). These methods are usually classified into three categories: supervised learning (learning with a teacher), uncontrolled learning (learning without a teacher) and reinforced learning (learning with reinforcement). These three categories group different methods, including neural networks, deep learning, etc.

Paragraph P of the European Parliament's resolution concerning Civil Law Rules on Robotics 2015/2103 (INL) dated 16 February 2017 takes into account the fact that, in the long run, it is likely that artificial intelligence may exceed human intellectual potential. In the nearest future, the chance of using such technologies in courts of general jurisdiction of Ukraine and in the sphere of criminal proceedings of Ukraine can be assessed as extremely high, and the scope of its application is not limited to work of artificial intelligence in courts. We can also talk about work of artificial intelligence in the sphere of activities performed by prosecutor and police. Therefore, practice of using mathematical algorithms and software that processes big data in the sphere of criminal proceedings with further making proceeding decisions, requires a substantial research.

\section{Literature review}

Issues related to research of artificial intelligence in procedural activities, problems of criminal law and legal regulation of artificial intelligence were researched by Sartor, L. Karl Branting "Judicial Application of Artificial Intelligence" (Sartor, 1998), G. Hallevy "When Robots Kill: Artificial Intelligence under Criminal Law" (Hallevy, 2015), K. BrennanMarquez, S. Henderson "Artificial Intelligence and Role-Reversible Judgment”, Ronald J. Allen "Artificial Intelligence and Evidentiary Process: Challenges of Formalism and Computation" (Allen, 2001), T. S. Zaplatina "Artificial Intelligence in the Issue of Making Judicial Decisions" (Zaplatina, 2019), O. E. Radutnyi "Artificial Intellect as a Subject in Criminal Law" (Radutnyi, 2017) and others. The sphere related to artificial intelligence in criminal proceedings in Ukraine remains weakly researched. 
REVISTA DE LA UNIVERSIDAD DEL ZULIA. 3é época. Año 13 N 36, 2022

Yevhen Leheza et al. /// Foreign experience and international legal standards for the application ... 276-287 DOI: http://dx.doi.org/10.46925//rdluz.36.18

\section{Materials and methods}

The research starts from the analysis of documentary sources and is based on the dialectical method for the knowledge of the facts of social reality; This method largely forms the basis for formally legal and comparatively legal approaches.

Using the dialectical method the modern conceptual base and the issue of legal technologies as instruments of applying artificial intelligence in judicial systems of developed states is formulated and its use in criminal proceedings of Ukraine are analyzed. The officially dogmatic method contributed to the development of the author's explanation of the up-todate state, problems, problems and practical role of legal technologies for further development and improvement of artificial intelligence application in the judicial systems of developed states and analysis of its use in criminal proceedings of Ukraine. The officially legal method gave an opportunity to offer directions and types of using legal technologies for artificial intelligence application in court systems of developed countries and to analyze prospects of its use in criminal proceedings of Ukraine.

\section{Results and discussion}

The European ethical Charter on the use of Artificial Intelligence in judicial systems and their environment dated December 3-4, 2018 provides a narrow definition of the following terms: artificial intelligence, algorithm, machine learning, big data, database, expert systems, neural networks, etc. Artificial intelligence is defined as a set of scientific methods, theories and techniques aimed at machine-based reproduction of human cognitive abilities. Modern developments seek to make machines perform complex tasks previously performed by humans. However, the term "artificial intelligence" is criticized by experts who distinguish between "strong" artificial intelligence, which can contextualize specialized and diverse problems completely autonomously, and "weak" or "moderate" artificial intelligence (which is highly effective in the sphere of "machine learning").

There are several legal services/systems in the world that use artificial intelligence:

- In France - Doctrine.fr (search system), Prédictice (analysts, except criminal cases), case Law Analytics (analysts, except criminal cases), Juris Data Analytics - LexisNexis (search system, analytics, except criminal cases);

- In the UK - Luminance (analytics), HART - Harm Assessment Risk Tool (analytics, 
REVISTA DE LA UNIVERSIDAD DEL ZULIA. 3é época. Año 13 N 36, 2022

Yevhen Leheza et al. /// Foreign experience and international legal standards for the application ... 276-287 DOI: http://dx.doi.org/10.46925//rdluz.36.18

criminal cases, risk assessment);

- In the United States of America - Watson/Ross - IBM (analytics), Lex Machina LexisNexis (analytics), COMPAS - corrective offer Management Profiling for alternative sanctions are used by US courts to assess likelihood of defendant's recidivism and to analyze previous misconducts;

- In Argentina - Prometea (analysts, civil and administrative cases)

- In China - Compulsory Similar cases Search and Reporting mechanism (analytics) is used in the Supreme People's Court of the People's Republic of China.

The most powerful systems of the presented list work in courts and police and help judges make procedural decisions. In the United States of America there is a COMPAS (corrective Offshore Management Profiling for alternative sanctions) system, which was used by the state courts of New York, Wisconsin, California, Florida in Broward County as well as by courts of other jurisdictions in the United States. COMPAS software uses an algorithm to assess the potential risk of a repetition of crime. According to the COMPAS user manual, the scales were designed using behavioral and psychological constructions "which are very important for the recurrence of crimes and criminal careers." The COMPAS system estimates not just the risk, but also nearly two dozen so-called "criminogenic needs" that relate to the basic theories of crime, including "criminal personality", "social isolation", "drug abuse" and "living/stability". Defendants in each category are classified as low, medium or high risk personalities (Lu, 2019).

In Ukraine, similar work is performed by staff of the probation body within preparation of pre-trial reports, supervisory and penitentiary probations. It should be noted that in Ukraine probation programs have only just begun to develop and it is somewhat premature to talk about the use of artificial intelligence in the preparation of a pre-trial reports, but an analogy can be used for a comparative analysis of existing artificial intelligence technologies and work of probation staff. According to parts 1, 3 of Art. 9 of the Law of Ukraine "On Probation", pre-trial probation is the provision of the court with formalized information that characterizes the respective accused person, in order the court could make a decision on the level of his/her responsibility. A pre-trial report on the accused person must contain: Social and psychological characteristics; assessment of risks of repeated criminal offenses; conclusion on the possibility of correction without restriction of liberty or 
REVISTA DE LA UNIVERSIDAD DEL ZULIA. 3é época. Año 13 N 36, 2022

Yevhen Leheza et al. /// Foreign experience and international legal standards for the application ... 276-287 DOI: http://dx.doi.org/10.46925//rdluz.36.18

imprisonment for a certain period of time (Law of Ukraine, 2015). According to parts 1, 2 of Art. 314-1 of the Criminal Procedure Code of Ukraine in order to provide the court with information that characterizes the accused person, as well as for making a court decision on the level of punishment, a representative of the authorized probation body shall prepare a pre-trial report by court order. A pre-trial report shall be compiled concerning a person accused of committing a minor or medium crime or a serious crime with the lower limit of punishment never exceeding five years of imprisonment. A pretrial report on a juvenile accused aged 14 to 18 shall be compiled regardless of the gravity of the crime committed, except in cases provided for by the Criminal Procedural Code of Ukraine. (Law of Ukraine, 2012).

No doubt, for a court is an advantage when such reports are compiled by an artificial intelligence in automatic mode with an assessment of recidivism risks. But such a report cannot be a proof of guilt in committing a crime. The proof procedure based on objective evidence differs from the automated data analysis performed by a system of artificial intelligence. When assessing risks, artificial intelligence takes data on a certain accused person from the database, analyzes these data using mathematical algorithms, and makes a report providing assessment the relevant risks. The more data, the higher accuracy of the report is. However, if the artificial intelligence takes into account data that will be artificially created or falsified, will be based on incorrect translation, incorrect expert's conclusion and explanations, knowingly false testimony of a witness, victim, suspect, accused will be taken into account. All these circumstances may affect correctness of artificial intelligence's conclusion.

In May 2016, a report ${ }^{5}$ was published in the United States; according to this report artificial intelligence was accused of racism. For example, a computer program used by an American court to assess risk was biased against African Americans ("black prisoners" is used in the original). The Correctional Offender Management Profiling for Alternative Sanctions (COMPAS) program was more inclined to mislabeling African-American defendants ("black defenders" is used in the original) with a possible repetition of offense almost twice as significant as in case with white people (45\% to $24 \%$ ), according to a journalistic investigation by ProPublica (Halaburda et al., 2021). This was also stated in the European ethical Charter on the use of Artificial Intelligence in judicial systems and their 
REVISTA DE LA UNIVERSIDAD DEL ZULIA. 3é época. Año 13 N 36, 2022

Yevhen Leheza et al. /// Foreign experience and international legal standards for the application ... 276-287 DOI: http://dx.doi.org/10.46925//rdluz.36.18

environment dated December 3-4, 2018, which stated that ProPublica found discrimination in the algorithm used in the COMPAS software intended to assess the risk of offense repetition, when the judge must determine the sentence individually (Leheza et al., 2018).

Criticism of the COMPAS system is a critique of commercial algorithms for assessing the risk of rime repetition as well as for assessing work of artificial intelligence in courts. But the main point is that the COMPAS system is applied exactly in criminal proceedings, it simplifies the working process of judges on making proceeding decisions and improves efficiency of court work. The negative experience of applying artificial intelligence in courts will be used to correct future mistakes. An extract from the decision made by the Supreme Court of Wisconsin in the case of Wisconsin vs. Lomis states: "It is important to take into account such instruments as COMPAS, continue changing and developing. The problems we face today can very well be changed in future; better tools can be developed (Leheza et al., 2021). As data changes, our use of evidence-based tools must also change. The justice system should keep pace with the research and constantly evaluate application of these tools."

Harm Assessment Risk Tool (HART) artificial intelligence system is very interesting for this research (Leheza et al., 2021). HART (Harm Risk Assessment Tool) was developed in partnership with Cambridge University and is now being tested in the UK. This machinelearning technology used Durham Police Archives from 2008 to 2012 to study the decisions made by police officers during this period of time... Machine learning is expected to assess risks, taking into account about thirty factors, some of which are not related to crimes performed (for example, ZIP code and gender). Risks concerning suspects are divided into categories: low, medium and high level. In tests conducted in early 2013, HART forecasts found 98\% effectiveness in predicting low risk and 88\% effectiveness in predicting high risk of recidivism. In this experimental phase, the HART system will have a purely advisory value for judges. Auditing of HART functioning and reliability of its conclusions will be conducted regularly by police (Leheza et al., 2021).

Analysis of the HART system gave us an opportunity to conclude that using such a system of artificial intelligence in work of the Ukrainian police, risks identified by such a system could be transferred to courts for making proceeding decisions on suspects and accused persons. For courts, this is an additional information which can be taken into account by judges when evaluating the evidence and making a proceeding decision. An 
REVISTA DE LA UNIVERSIDAD DEL ZULIA. 3é época. Año 13 N 36, 2022

Yevhen Leheza et al. /// Foreign experience and international legal standards for the application ... 276-287 DOI: http://dx.doi.org/10.46925//rdluz.36.18

advantage of working with big data is that the whole "history" of a suspect is recorded in a proper report (Hassani et al., 2020).

In his article "UK police are Using AI to Inform Custodial Decisions - but It could be Discriminating Against the Poor," M. Berges notes that in order to assess low, medium and high risks the HART system uses data from 34 various categories covering age, gender and history of offenses. These data categories contain information about the postal code. Police officers are now removing "data" with postal codes that include the first four digits of Durham's indexes from the HART system (UK Police are Using AI to Inform Custodial Decisions - but It Could be Discriminating against the Poor, 2018).

Again, one can see a discriminatory feature in operation of artificial intelligence, and this discriminatory feature is being worked on by the British police and scientists. When developing similar systems in Ukraine, it is necessary to take into account such mistakes and possibly take into account other social features in order to avoid discriminatory factors.

Prometea system of artificial intelligence should be considered separately. The presented information was taken from an article on LegalHub and it in the best possible way demonstrates operation of artificial intelligence in prosecutor's office and court concerning efficiency and procedural economy. For example, the Buenos Aires District Prosecutor's Office in Argentina summed up interim results of testing the Prometea software application, which can make and issue a court decision from a number of categories of civil and administrative cases in 10 seconds. Prometea analyzed about 300 thousand scanned court decisions from 2016 to 2017, including 2 thousand resolutions ${ }^{3}$. In Argentina, district prosecutors make decisions, and presiding judges either dismiss these decisions and write their own ones, or simply approve them. Now, as soon as a new case enters the prosecutor's office, Prometea compares the invoice with the most relevant decisions in its database - and this allows the program to guess in about 10 seconds how the court will react to the situation. As a result of applying the program, prosecutors were released from large arrays of routine activities. According to the head of the office, fifteen of his lawyers in just six weeks cope with the volume of work that before needed about six months to be done. Prometea is also highly praised by judges, who have so far approved 33 of the 33 decisions proposed by this system (it is now used in 84 other cases under consideration) (Leheza et al., 2021).

China is also making progress in using of big data and introduction of artificial 
REVISTA DE LA UNIVERSIDAD DEL ZULIA. 3a época. Año $13 \mathrm{~N}^{\circ}$ 36, 2022

Yevhen Leheza et al. /// Foreign experience and international legal standards for the application ... 276-287 DOI: http://dx.doi.org/10.46925//rdluz.36.18

intelligence technology in the justice system. The above information appeared on several resources. During the latest judicial reform of Chinese courts, from 2014 to 2017, China's Supreme People's Court promoted a system of "similar court decisions for similar cases" in order to ensure an effective judicial oversight. The system of similar court decisions for similar cases mentioned by the Supreme People's Court of China means that criteria for making court decisions must be in line with the case a judge is considering and previous cases, which have been completed by the respective court and the Supreme Court as well as in line with other similar cases. The Supreme People's Court of China hopes to achieve "similar sentences in similar cases" through the use of artificial intelligence (AI) technology. Such an aspiration to standardize court decisions "in similar cases" means a desire to automate court decisions and create a model of standard decisions in mass proceedings (Wamba-Taguimdje et al., 2020).

Unfortunately, this application only works with civil and administrative cases, but it is possible that in future, the developer of the Prometea application, programmer Ignacio Raffa will be able to supplement appropriate algorithms of the program for Prometea's operation in criminal proceedings. In Ukraine, such an application could help investigating judges in deciding on measures to ensure criminal proceedings or in choosing precautionary measures. The main point is that Prometea is not only able to determine a court decision in 10 seconds and the program is also able to execute it; and the result of Prometea's operation in court is thirty-three court decisions of thirty-three ones. In percentage it is 100\% positive result of artificial intelligence operation. The above-mentioned program of artificial intelligence has become interesting for the UN and the World Bank, which is mentioned in the article. Thus, automation of Buenos Aires justice system has already attracted interest of the United Nations and the World Bank. The developer of the application Raffa said that he and his three colleagues hope to introduce similar systems in the USA and Europe by the spring of 2019 (Leheza et al., 2020).

The Supreme People's Court of China demands that before making decisions judges should search for similar cases and related cases in order to ensure that the criteria of such cases are met. This practice is called the Compulsory Similar Cases Search and Reporting Mechanism (Leheza et al., 2021). The Supreme People's Court of China considers the possibility to adopt this mechanism because of confidence in the technologies and artificial 
REVISTA DE LA UNIVERSIDAD DEL ZULIA. 3a época. Año $13 \mathrm{~N}^{\circ}$ 36, 2022

Yevhen Leheza et al. /// Foreign experience and international legal standards for the application ... 276-287 DOI: http://dx.doi.org/10.46925//rdluz.36.18

intelligence (AI) data of Chinese courts. First, Chinese courts have made significant progress in big data technology. Chinese courts have included all court decisions throughout the country in the database and are now digitizing case files that will make it easier to find a judge. Second, Chinese courts have tried to use artificial intelligence techniques to provide aid and supervise judges. Up to date this function is used mainly in criminal cases to monitor correctness of judges' sentences (Zaplatina, 2019).

But even such progressive measures to standardize similar court decisions according to the relevant criteria are criticized. Radutnyi notes that during communication with some judges who use these systems, their feedback is mainly as follows: First, "similar cases" prompted by these systems are not accurate enough, and the similarities with the cases heard by judges are not sufficient. This means that judges do not have a significant guideline. Second, experienced judges do not need such systems. However, inexperienced judges are willing to learn hearing cases using an artificial intelligence system. Therefore, this system is suitable for preparation of new judges. Third, the technology of artificial intelligence needed by judges most is "automatic generation of court decisions": An artificial intelligence system "reads" case materials, extracts key information from them, and then automatically generates judgments based on criteria of justice for similar cases (Radutnyi, 2017). Given the fact that in recent years Chinese judges have fallen into the "surge of load" courts should urgently use this technology to reduce the workload on judges.

\section{Conclusion}

Given the operation of the COMPAS and HART systems, artificial intelligence is able to assess risks of recidivism and can be successfully used in preparation of pre-trial reports in criminal proceedings, as well as in supervisory and penitentiary probations in Ukraine. When dealing with procedural issues regarding measures to ensure criminal proceedings or selection of preventive measures, artificial intelligence can help investigators, taking into account the operation experience of Prometea application. By means of using the experience of Chinese courts in generating big data and implementing artificial intelligence systems using the Compulsory Similar Cases Search and Reporting Mechanism, it is possible to create a project for automatic generation of court decisions in Ukraine.

In fact, the use of artificial intelligence creates a model of digital decision automation. Such automation simplifies the decision-making procedure in similar procedures, which, of 
REVISTA DE LA UNIVERSIDAD DEL ZULIA. $3^{\text {a }}$ época. Año $13 \mathrm{~N}^{\circ}$ 36, 2022

Yevhen Leheza et al. /// Foreign experience and international legal standards for the application ... 276-287 DOI: http://dx.doi.org/10.46925//rdluz.36.18

course, improves efficiency and simplifies the procedural decision-making procedure in terms of economy. For the use of artificial intelligence in the Ukrainian judicial system, it is necessary to take appropriate legislative decisions regulating public relations in a particular area of human activity. The European Ethical Charter on the use of artificial intelligence in judicial systems and their environment, from December 3-4, 2018, has already laid the foundations for future legislative decisions on the introduction of artificial intelligence in courts of general jurisdiction from Ukraine.

\section{References}

Allen, Ronald (2001). Artificial intelligence and the evidentiary process: The challenges of formalism and computation. Artificial Intelligence and Law. URL: https://link.springer.com/article/10.1023/A:1017941929299

Halaburda, Nadiia; Leheza Yevhen; Chalavan, Viktor; Yefimov, Volodymyr; Yefimova, Inna (2021). Compliance with the principle of the rule of law in guarantees of ensuring the legality of providing public services in Ukraine. Journal of law and political sciences. Vol. 29, Issue 4, 100121.

Hallevy, Gabriel (2015). When robots kill: artificial intelligence under criminal. University of Toronto Faculty of Law. URL: https:/www.thefreelibrary.com/When+Robots+Kill\%3a+Artificial+Intelligence+Under+th e+Criminal+Law. - a0421909790

Hassani, Hossein; Silva, Emmanuel S.; Unger, Stephane; Maedeh TajMazinani; Mac Feely, Stephen (2020). "Artificial Intelligence (AI) or Intelligence Augmentation (IA): What Is the Future?" AI 1, no. 2: 143-155. https://doi.org/10.3390/ail020008

Law of Ukraine (2012). Criminal procedural code of Ukraine: Law of Ukraine 13.06.2012 № 465l-VI. URL.: https://zakon.rada.gov.ua/laws/show/465l-17

Law of Ukraine (2015). About probation: Law of Ukraine 26.02.2015 № 160-VIII. URL: https://zakon.rada.gov.ua/laws/show/160-19

Leheza, Yevhen; Tiutchenko, Svitlana; Stanina, Olha; Shatrava, Serhii; Rezanov Serhii (2021). Uso y protección del suelo: regulación legal y experiencia extranjera. Revista De La Universidad Del Zulia, 12(33), 70-81. DOI: https://doi.org/10.46925//rdluz.33.06

Leheza, Yevhen; Dorokhina, Yuliia; Shamara, Oleksandr; Miroshnychenko, Serhii. Moroz, Vita. (2021). Citizens 'participation in the fight against criminal offences: political and legal aspects. Cuestiones Políticas, 39(69), 212-224. DOI: https://doi.org/10.46398/cuestpol.3969.12

Leheza, Yevhen; Filipenko, Tatiana; Sokolenko, Olha; Darahan, Valerii; Kucherenko, Oleksii. (2020). Ensuring human rights in Ukraine: problematic issues and ways of their solution in 
REVISTA DE LA UNIVERSIDAD DEL ZULIA. $3^{a}$ época. Año $13 \mathrm{~N}^{\circ}$ 36, 2022

Yevhen Leheza et al. /// Foreign experience and international legal standards for the application ... 276-287 DOI: http://dx.doi.org/10.46925//rdluz.36.18

the social and legal sphere. Cuestiones políticas. Vol. 37 №o 64 (enero-junio 2020). P. 123-136. DOI: https://doi.org/10.46398/cuestpol.3764.10

Leheza, Yevhen; Odyntsova, Iryna; Dmytrenko, Natalia. (2021). Teoría y regulación legal del apoyo informativo de los procedimientos administrativos en Ucrania. Ratio Juris UNAULA, 16 (32). P. 29l-306. DOI: https://doi.org/10.24142/raju.vl6n32al2

Leheza, Yevhen; Savielieva, Maryna; Dzhafarova, Olena. (2018). Structural and legal analysis of scientific activity regulation in developed countries. In: Baltic journal of economic studies. Vol. 4, No. 3, pp. 147-157. DOI: https://doi.org/10.30525/2256-0742/2018-4-3-147-157

Lu, Yang (2019). Artificial intelligence: a survey on evolution, models, applications and future trends. Journal of Management Analytics. Vol. 6. Issue 1. P. 1-29. DOI: https://oi.org/10.1080/23270012.2019.1570365

Radutnyi, Alexander (2017). Artificial intelligence as a subject of crime. Information and law. URL: http://ippi.org.ua/ sites/default/files/

Sartor, Giovanni (1998). Branting, Judicial Applications of Artificial Intelligence. Springer Science+Business Media. . URL: https://link.springer.com/chapter/10.1007/978-94-0159010-5_1

UK police are using AI to inform custodial decisions - but it could be discriminating against the poor. (2018). WIRED. URL.: 〈https://www.wired.co.uk/article/police-ai-uk-durhamhart-checkpoint-algorithm-edit>

Wamba-Taguimdje, S.-L., Fosso Wamba, S., Kala Kamdjoug, J.R. and Tchatchouang Wanko, C.E. (2020), "Influence of artificial intelligence (AI) on firm performance: the business value of AI-based transformation projects", Business Process Management Journal, Vol. 26 No. 7, pp. 1893-1924. https://doi.org/10.1108/BPMJ-10-2019-0411.

Zaplatyna, Tatiana Sergeevna. (2019). Artificial intelligence in the issue of adjudication Bulletin of the University named after O.E. Kutafin. URL: https://cyberleninka.ru/article/n/iskusstvennyy-intellekt-v-voprose-vyneseniya-sudebnyhresheniy-ili-ii-sudya 